\title{
APLIKASI PENGENALAN DAN SIMULASI ALAT MUSIK SAPE' BERBASIS ANDROID
}

\author{
Ghani Kurniasaid ${ }^{1)}$; Heru Supriyono ${ }^{2)}$ \\ 1) Program Studi Informatika, Universitas Muhammadiyah Surakarta \\ 2) Program Studi Teknik Elektro, Universitas Muhammadiyah Surakarta \\ ${ }^{1)}$ ghani4899@gmail.com; ${ }^{2)}$ herusupriyono@ums.ac.id
}

\begin{abstract}
The development of Information and communication technology in this era has shown various result and thrive rapidly. One of the examples which can be observed in society especially on the rising generation is the using of the smartphone. The function of a smartphone is not only to send a message and give feedback on it but also to search for information. Moreover, the smartphone can be used to entertain people. A lack of the utilization of smartphone as a learning media for young generation becomes one of the problems that occur in this current globalization. The traditional musical instrument is one of the cultural heritage which is most of their connoisseur have decreased sharply. Based on that problem, we designed a simulation cellular application and introduce Sape as a traditional musical instrument with an android system for preserving the traditional musical instrument. This application will be served in a 2D form using engine game Construct 2. Multimedia Development Life Cycle (MLDC) is using as a method which contains concept, design, material collection, construction, verification, and distribution. This research used the waterfall process model as the design approach. This research is using black box method for application testing and using Likert Scale questionnaire as the data collection method. The black box method shows valid results and this application is already well functioned according to the required needs. Data collection from the questionnaire has obtained a result that equals $74.53 \%$. It can be concluded that this application received a positive response and can help people to learn Sape' musical instrument.

Keywords: Application, Android, Sape', Construct 2, Multimedia Development Life Cycle.
\end{abstract}

\section{PENDAHULUAN}

Indonesia adalah negara yang besar akan nilai-nilai tradisi dan kebudayan. Setiap daerah memiliki ciri khas masing-masing budaya yang beragam. Salah satu suku Indonesia yang kaya akan budaya adalah suku Dayak yang berada di Kalimantan Timur. Suku Dayak memiliki berbagai kesenian salah satunya adalah kesenian musik tradisional seperti entebong, keledik, kangkuang dan Sape'.

Seiring dengan berkembangnya zaman dan kemajuan teknologi pada saat ini, kemudahan dalam mengakses informasi merupakan salah satu kebutuhan penting dalam masyarakat. Telepon seluler atau smartphone tidak hanya digunakan untuk menelpon maupun berkirim pesan. Masyarakat cenderung menginginkan telepon seluler yang dapat membantu kegiatan sehari - hari. Berbeda dengan pesatnya kemajuan teknologi saat ini, perkembangan alat musik tradisional semakin kehilangan penggemarnya.

Penelitian ini bertujuan untuk merancang sebuah aplikasi pengenalan dan simulasi sebagai sarana pemahaman alat musik tradisional Sape' kepada masyarakat berbasis sistem operasi android. Selain itu, sejauh ini juga belum adanya penelitian tentang alat musik Sape' berbasis android. Dengan adanya aplikasi ini diharapkan dapat membantu mengenalkan dan mewariskan alat musik Sape' dengan konsep yang mudah dikenali dikalangan masyarakat

\section{TINJAUAN PUSTAKA}

Sape' adalah alat musik yang berasal dari suku Dayak di Kalimantan Timur. Beberapa masyarakat suku Dayak yang besar menetap di wilayah Kalimantan, Indonesia dan Malaysia Timur yang telah melalui era zaman yang sangat lama. Oleh sebab itu, masyarakat suku Dayak pastinya memiliki fase dan kebudayaan beserta semua tradisinya. Beberapa wujud hasil kebudayaan masyarakat Dayak adalah alat musik tradisional yang memiliki bunyi dan fungsi yang khas [1].

Kurangnya kepedulian masyarakat Indonesia terhadap musik tradisional disebabkan oleh beberapa faktor, seperti minimnya pemahaman dan pengenalan mengenai alat musik tradisional sejak dini, kurangnya ketersediaan dan keterbatasan 
tenaga ahli, remaja zaman sekarang memandang kesenian musik tradisional belum terlalu mengikuti perkembangan zaman dan sudah tertinggal jauh dengan alat musik modern yang sudah mulai merebut animo masyarakat Indonesia khususnya pada tingkatan remaja [2].

Dengan penggunaan multimedia, penyampaian informasi akan menjadi lebih menarik dan mempermudah pengguna dalam mendapatkan informasi tersebut [3]. Aplikasi ini nantinya akan disajikan di platform Android. Android merupakan suatu sistem operasi untuk telepon seluler berbasiskan Linux yang menyajikan platform terbuka bagi pengembang untuk membangun aplikasi sehingga dapat digunakan oleh berbagai macam piranti bergerak [3]

Hampir $75 \%$ anak muda lebih tertarik pada teknologi musik modern, demikian 50\% dari mereka setuju bahwa teknologi musik membantu mereka untuk belajar musik lebih mudah [4]. Beberapa manfaat langsung terhadap keterlibatan musik adalah ketentraman emosional dan fisik dari mereka yang memainkan alat musik maupun mendengarkan akan membuat peningkatan rasa percaya diri, pengembangan ketrampilan sosial dan jaringan sosial yang lebih luas [5].

\section{METODE PENELITIAN}

Metode pengembangan sistem yang dipakai adalah sistem Multimedia Development Life Cycle (MDLC), Metode ini terdiri dari enam tahap yaitu konsep (concept), desain (design), pengumpulan materi (material collecting), pembuatan (assembly), pengujian (testing), dan distribusi (distribution) yang menggunakan model waterfall seperti pada Gambar 1.

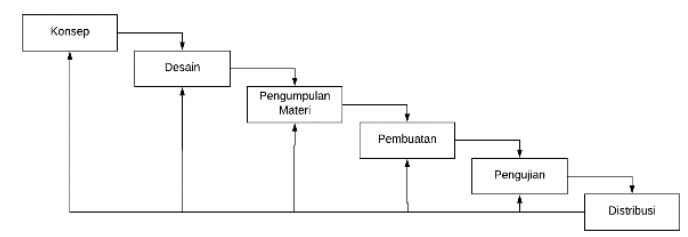

Gambar 1. Perancangan system dengan pendekatan waterfall

\subsection{Konsep}

Aplikasi yang akan dibuat dalam penelitian ini bertujuan untuk membuat simulasi dan pengenalan salah satu alat musik tradisional dari Kalimantan Timur, yaitu Sape' dan diharapkan dapat membantu mengenalkan dan melestarikan alat musik tradisional Sape' dengan konsep pada perangkat mobile. Penelitian ini mempunyai ruang lingkup pada masyarakat umum serta dikhusukan untuk generasi muda. Aplikasi simulasi dan pengenalan ini akan diberi nama "Aplikasi Alat Musik Tradisional Sape'”. Nama ini dipilih agar pengguna dapat mengetahui bahwa ada alat musik yang bernama Sape'.

Sebagai landasan dalam pembuatan aplikasi pada tahap selanjutnya maka perlu dirancang sebuah skenario agar aplikasi yang akan dibuat sesuai dengan apa yang diharapkan. Rancangan dari aplikasi "Simulasi Alat Musik Tradisional Sape"' yaitu sebagai berikut :

1. "Aplikasi Alat Musik Tradisional Sape"” terdiri dari tiga buah halaman yaitu halaman menu utama, halaman sejarah, dan halaman main.

2. Pada halaman utama pengguna dapat memilih menu yang diinginkan seperti menu main dan menu sejarah, serta terdapat audio backsound dari alat musik Sape'.

3. Pada halaman sejarah pengguna dapat mengetahui sejarah alat musik Sape', disebelah kanan halaman terdapat pilihan menu yang terdiri dari pengertian, asal-usul, jenis, fungsi, cara main, gambar dan video dari alat musik Sape'.

4. Pada setiap menu halaman sejarah, apabila menu ditekan maka akan mengeluarkan audio dari text yang terdapat pada antarmuka halaman. Sedangkan pada menu video terdapat video dari alat musik Sape'.

5. Pada halaman main pengguna dapat menyimulasikan senar dari alat musik Sape' yaitu bass 1 (mi) pada senar 5 , bass 2 (fa) pada senar 4, bass 3 (do) pada senar 3 , bass 4 (sol) pada senar 2. Sedangkan pada senar 1 digunakan sebagai melody dengan nada tangga antara lain do, re, $\mathrm{mi}, \mathrm{fa}$, sol dan la. Serta adanya tanda nada tangga pada senar 2 sampai 5 untuk tangga nada bass. Sedangkan pada senar 1 terdapat tanda nada tangga melody pada tiap fret (seperti pada gitar). Terdapat juga tombol pengaturan untuk mematikan volume pada bagian kiri atas halaman, apabila ditekan audio pada halaman main akan di mute begitu pula sebaliknya apabila tombol ditekan kembali makan audio pada halaman main akan hidup.

\subsection{Desain}

Pada tahap ini, pebuatan aplikasi diterapkan berdasarkan perancangan dari konsep yang telah dibuat. Desain aplikasi 
dirancang menggunakan use case yang dapat dilihat pada Gambar 2.

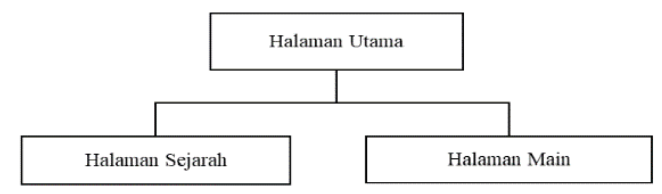

Gambar 2. Use case desain aplikasi

\subsection{Halaman Menu Awal}

Halaman menu awal adalah halaman yang akan muncul ketika aplikasi dijalankan. Pada halaman menu awal terdpat dua pilihan tombol menu yaitu :

1. Tombol Sejarah

2. Tombol Main

Pada antarmuka halaman menu awal juga terdapat logo dari aplikasi. Tampilan halaman menu awal dapat dilihat pada Gambar 3.

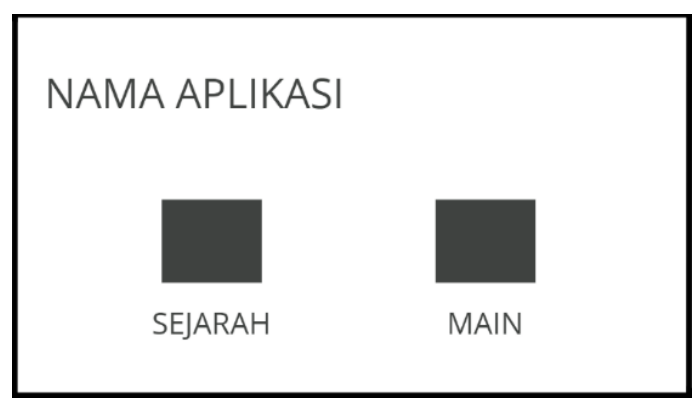

Gambar 3. Halaman menu awal

\subsection{Halaman Sejarah}

Halaman sejarah merupakan halaman dimana terdapat penjelasan tentang alat musik Sape'. Pada halaman ini juga terdapat tomboltombol dimana setiap tombol jika ditekan maka akan muncul penjelasan dari menu tersebut dan mengeluarkan audio membaca. Di halaman ini terdapat pula video tentang main alat musik Sape' dan cara membuatnya. Tampilan halaman sejarah dapat dilihat pada Gambar 4 dan Gambar 5 untuk video.

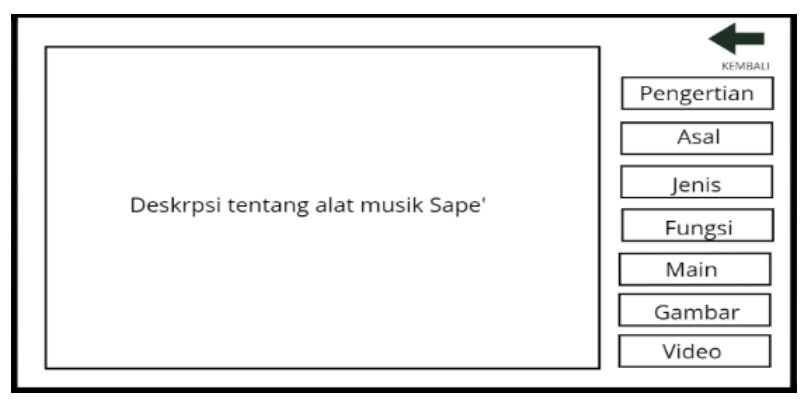

Gambar 4. Halaman sejarah

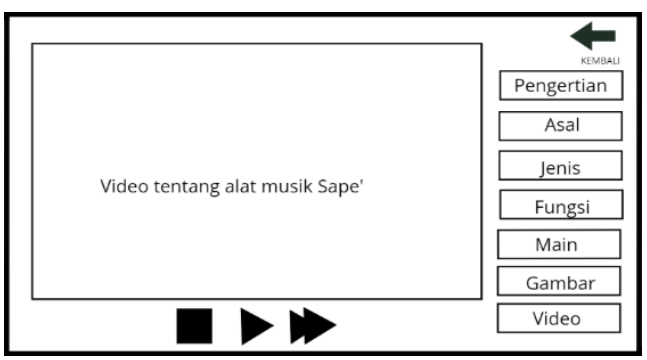

Gambar 5. Video pada halaman sejarah

\subsection{Halaman Main}

Halaman menu main adalah halaman berikutnya digunakan untuk memainkan alat musik Sape'. Pada halaman ini terdapat 5 senar yang masing-masing senar terdapat kunci pada tiap senar. Terdapat juga menu mute pada sisi kiri atas halaman. Tampilan dari animasi halaman main dapat dilihat pada Gambar 6.

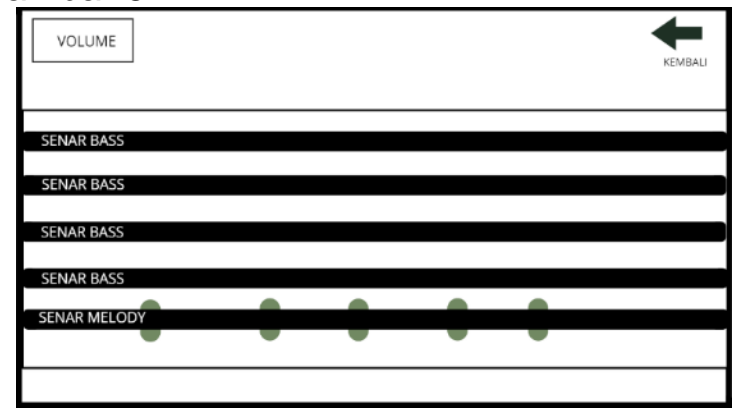

Gambar 6. Animasi halaman main

\subsection{Pengumpulan Materi}

Pada tahap ini dilakukan pengumpulan materi yang diperlukan dalam pembuatan aplikasi, yaitu berupa desain, gambar dan audio. Desain yang akan digunakan pada aplikasi sederhana, namun tetap memberikan tampilan aplikasi yang menarik dan gambar yang mudah diingat. Ditambahkan juga beberapa animasi untuk menambah tampilan lebih nyata. Serta audio yang digunakan pada aplikasi ini asli menggunakan petikan suara dari alat musik Sape'.

\subsection{Pembuatan}

Kebutuhan perangkat lunak dan keras yang akan digunakan dalam pembuatan aplikasi. Pertama perangkat lunak yang digunakan pada pembuatan aplikasi adalah sebagai berikut :

1. Microsoft Windows 10 Professional, sistem operasi ber-platform windows yang digunakan untuk mengembangkan dan membuat aplikasi ini.

2. Construct 2, game engine ber-platform windows yang berfungsi untuk merancang game berbasis dua dimensi. 
3. Corel Draw $X 7$, perangkat lunak berplatform windows yang berfungsi untuk merancang grafis berbasis vector

4. Adobe Photoshop CC 2017, perangkat lunak ber-platform yang berfungsi untuk mengolah foto, gambar serta pembuatan efek.

5. Audacity, perangkat lunak berbasis cross platform yang berfungsi untuk pengolahan audio pada aplikasi.

6. Vectr, perangkat lunak yang berfungsi untuk merancang grafis berbasis vector.

Untuk perangkat keras yang digunakan dalam penelitian ini menggunakan laptop dengan spesifikasi sebagai berikut :

1. Intel(R) Core(TM) i3-4030 CPU @ 1.90GHz

2. RAM $4,00 \mathrm{~GB}$

3. Hardisk $500 \mathrm{~GB}$

Serta perangkat keras tambahan yang digunakan untuk pengujian aplikasi ini menggunakan perangkat seluler yang memiliki sistem operasi android dengan minimal versi 5.0 (Lollipop) dan target 6.0 (Marsmellow). Uji coba aplikasi akan dilakukan pada perangkat seluler Xiaomi Redmi Note 4X dengan sistem android versi 6.0 (Marsmellow). Untuk spesifikasi dari Xiaomi Redmi Note 4X adalah sebagai berikut:

1. Octa-core $2.0 \mathrm{GHz}$ Cortex-A53

2. RAM 4 GB

3. Resolusi $1080 \times 1920$

\subsection{Pengujian}

Pada tahap ini penulis melakukan pengujian terhadap aplikasi yang telah dibuat. Pengujian dilakukan untuk mengetahui apakah aplikasi sudah sesuai dengan kebutuhan yang diperlukan. Dengan melakukan uji blackbox pada aplikasi seperti menu dan audio untuk mengatahui apakah sudah sesuai dengan fungsinya masing-masing.

\subsection{Distribusi}

Setelah tahap pengujian dilakukan, tahap selanjutnya adalah distribusi. Aplikasi "Simulasi Alat Musik Tradisional Sape" ini akan didistribusikan dalam bentuk file .apk. File apk nantinya akan ditransfer antar smartphone dengan aplikasi sharing aplikasi dan juga dapat diunduh melalui alamat https://drive.google.com/open?id=1 wnZ5ToaQ uCn1eEJA-iVJnKZVP-J_lj49.

\section{HASIL DAN PEMBAHASAN}

4.1 Hasil Pembuatan Aplikasi

Pembuatan pada aplikasi ini diterapkan bedasarkan perancangan yang telah dibuat sebelumnya sehingga dapat menciptakan aplikasi yang dapat bekerja sesuai dengan fungsinya. Berikut ini adalah tampilan aplikasi yang telah dibuat menurut susunan navigasi yang dapat dilihat pada Gambar 7.

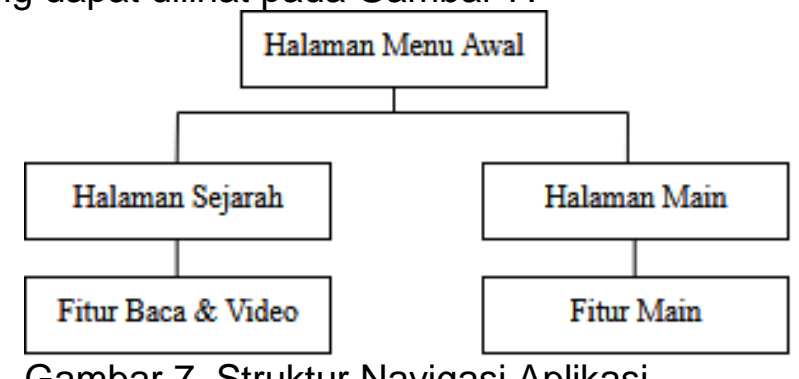

Gambar 7. Struktur Navigasi Aplikasi

\subsubsection{Halaman Menu Awal}

Halaman menu awal merupakan halaman yang akan tampil ketika aplikasi dijalankan. Pada halaman ini terdapat logo nama aplikasi dan dua pilihan menu yaitu:

1. Menu Main

2. Menu Sejarah

Tampilan halaman menu awal dapat dilihat seperti pada Gambar 8 .

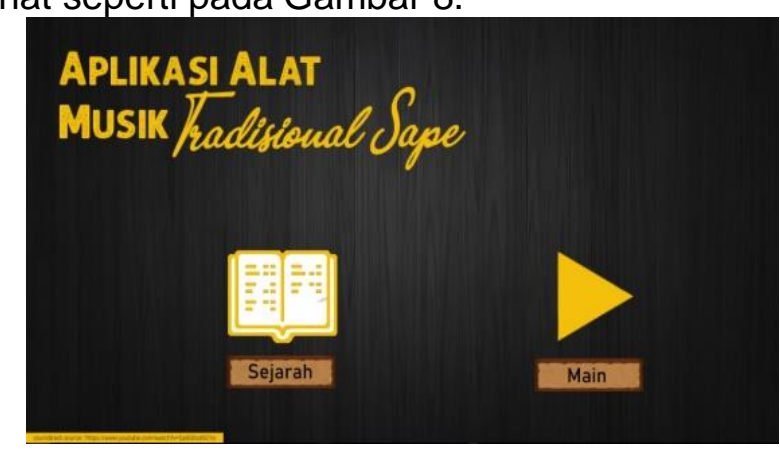

Gambar 8. Halaman menu awal

\subsubsection{Halaman Menu Sejarah}

Halaman ini menampilkan sejarah dan perkembangan mengenai alat musik Sape'. Pada sisi kanan terdapat menu seperti pengertian, asal-usul, jenis, fungsi, cara main, gambar dan video dari alat musik Sape' serta terdapat tombol kembali ke halaman menu awal. Tampilannya dapat dilihat pada Gambar 9 dan untuk gambar alat musik Sape' pada Gambar 10.

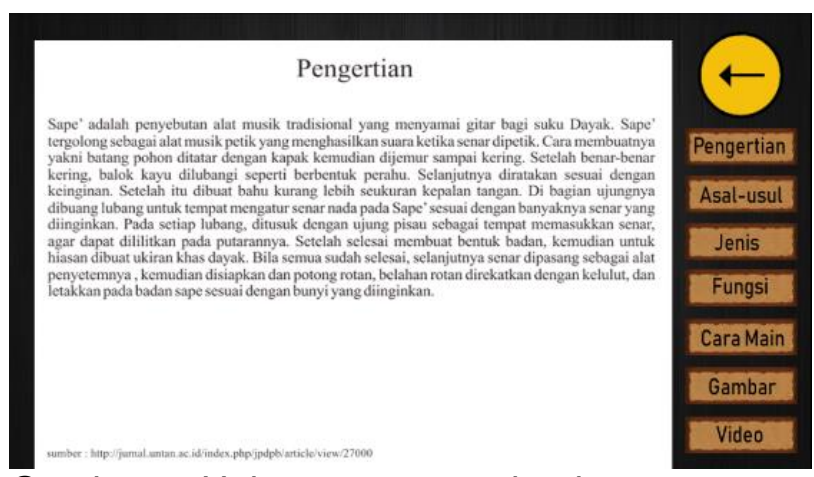

Gambar 9. Halaman menu sejarah 


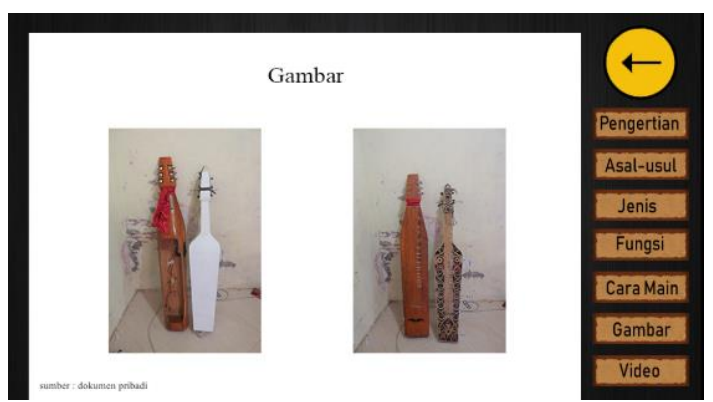

Gambar 10. Halaman menu sejarah

\subsubsection{Halaman Menu Main}

Setelah menekan tombol main pada halaman menu awal, pengguna akan ditujukan pada halaman main alat musik Sape'. Pada halaman ini terdapat terdapat lima senar, yaitu senar 2 sampai 5 berupa bass dengan nada tangga mi, fa, do, dan sol. Sedangkan pada senar satu terdapat 6 fret (seperti pada gitar) yang masing-masing memiliki nada tangga do, re. mi, fa, sol, dan la. Serta adanya tanda nada tangga pada senar 2 sampai 5 . Sedangkan pada senar 1 terdapat tanda nada tangga pada tiap fret pada alat musik Sape'. Serta terdapat tombol untuk mematikan audio. Untuk cara memainkan alat musik Sape' cukup dengan ditekan pada bagian senar melody dan bass yang telah disediakan beserta tanda kunci, makan akan keluar audio dari masing masing senar. Berbeda dengan memainkan alat musik Sape' yang di petik untuk memainkannya dan harus menghafalkan nada tangga pada tiap senar. Halaman ini juga terdapat tombol kembali ke halaman menu awal seperti pada Gambar 11.

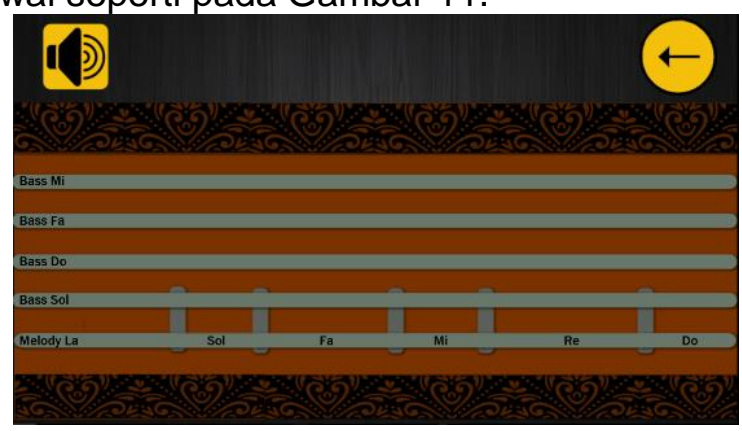

Gambar 11. Halaman main

\subsubsection{Pengujian Blackbox}

Pengujian aplikasi yang telah dibuat pada "Aplikasi Simulasi dan Pengenalan Alat Musik Tradisional Sape"' ini dilakukan menggunakan metode blackbox. Pada pengujian ini berisi susunan pengujian pada tombol dan audio yang terdapat pada aplikasi. Pengujian yang dilakunan menggunakan perangkat seluler Xiaomi Redmi Note 4X.

Pengujian ini dilakukan unuk mengecek fungsi dari aplikasi yang telah dibuat, apakah hasilnya sesuai dengan apa yang diharapkan. Pengujian ini juga dibuat untuk mengetahui adanya kesalahan yang sehingga dapat diberi solusi. Pengujian ini dapat dilihat pada Tabel 1.

Tabel 1. Tabel pengujian aplikasi

\begin{tabular}{|c|c|c|c|}
\hline $\begin{array}{l}\text { Nama } \\
\text { Pengujian }\end{array}$ & $\begin{array}{l}\text { Bentuk } \\
\text { Pengujian }\end{array}$ & $\begin{array}{l}\text { Hasil yang } \\
\text { Diharapkan }\end{array}$ & Hasil \\
\hline $\begin{array}{l}\text { Pengujian } \\
\text { buka } \\
\text { aplikasi }\end{array}$ & $\begin{array}{l}\text { Membuka } \\
\text { aplikasi }\end{array}$ & $\begin{array}{l}\text { Tampilnya } \\
\text { halaman } \\
\text { Menu Utama } \\
\text { pada aplikasi }\end{array}$ & Valid \\
\hline $\begin{array}{l}\text { Pengujian } \\
\text { tombol } \\
\text { Sejarah }\end{array}$ & $\begin{array}{l}\text { Menekan } \\
\text { tombol } \\
\text { Sejarah }\end{array}$ & $\begin{array}{l}\text { Tampilnya } \\
\text { antarmuka } \\
\text { pada halaman } \\
\text { Sejarah }\end{array}$ & Valid \\
\hline $\begin{array}{l}\text { Pengujian } \\
\text { tombol } \\
\text { Pengertian, } \\
\text { Asal-usul, } \\
\text { Jenis, } \\
\text { Fungsi, } \\
\text { Cara Main, } \\
\text { Gambar } \\
\text { dan Video } \\
\text { pada } \\
\text { halaman } \\
\text { sejarah }\end{array}$ & $\begin{array}{l}\text { Menekan } \\
\text { tombol } \\
\text { Pengertian, } \\
\text { Asal-usul, } \\
\text { Jenis, } \\
\text { Fungsi, } \\
\text { Cara Main } \\
\text { dan } \\
\text { Gambar, } \\
\text { dan Video }\end{array}$ & $\begin{array}{l}\text { Tampilnya } \\
\text { antarmuka } \\
\text { dari masing- } \\
\text { masing menu } \\
\text { pada halaman } \\
\text { Sejarah }\end{array}$ & Valid \\
\hline $\begin{array}{l}\text { Pengujian } \\
\text { tombol } \\
\text { Kembali }\end{array}$ & $\begin{array}{l}\text { Menekan } \\
\text { tombol } \\
\text { Kembali } \\
\text { pada } \\
\text { halaman } \\
\text { Sejarah }\end{array}$ & $\begin{array}{l}\text { Tampilnya } \\
\text { antarmuka } \\
\text { Menu Utama }\end{array}$ & Valid \\
\hline $\begin{array}{l}\text { Pengujian } \\
\text { tombol Main }\end{array}$ & $\begin{array}{l}\text { Menekan } \\
\text { tombol Main }\end{array}$ & $\begin{array}{l}\text { Tampilnya } \\
\text { antarmuka } \\
\text { pada halaman } \\
\text { Main } \\
\end{array}$ & Valid \\
\hline $\begin{array}{l}\text { Pengujian } \\
\text { senar } 1 \\
\text { sampai } \\
\text { senar } 5\end{array}$ & $\begin{array}{l}\text { Menekan } \\
\text { tombol } \\
\text { senar } 1 \\
\text { sampai } \\
\text { senar } 5\end{array}$ & $\begin{array}{l}\text { Keluarnya } \\
\text { audio dari } \\
\text { masing- } \\
\text { masing senar }\end{array}$ & Valid \\
\hline $\begin{array}{l}\text { Pengujian } \\
\text { tombol } \\
\text { mute }\end{array}$ & $\begin{array}{l}\text { Menekan } \\
\text { tombol } \\
\text { mute }\end{array}$ & $\begin{array}{l}\text { Mematikan } \\
\text { audio pada } \\
\text { halaman Main }\end{array}$ & Valid \\
\hline $\begin{array}{l}\text { Pengujian } \\
\text { tombol } \\
\text { unmute }\end{array}$ & $\begin{array}{l}\text { Menekan } \\
\text { tombol } \\
\text { unmute }\end{array}$ & $\begin{array}{l}\text { Menghidupkan } \\
\text { audio pada } \\
\text { halaman Main }\end{array}$ & Valid \\
\hline
\end{tabular}

\subsubsection{Pengujian Aplikasi dengan Mwtode} Kuisioner

Pengujian aplikasi oleh pengguna dilakukan langsung oleh sasaran aplikasi, yakni kalangan muda dan masyarakat umum. Proses pengujian dilakukan dengan meminta pengguna menggunakan "Aplikasi Penenalan dan Simulasi Alat Musik Sape"' dan dilanjutkan dengan mengisi kuisioner dan pendapat tentang aplikasi.

Setiap responden akan disediakan 5 sampel pertanyaan yang terdapat 5 jawaban, yaitu, Sangat Tidak Setuju (STS), Tidak Setuju (TS), Netral (N), Setuju (S), Sangat Setuju (SS) 
dan Masing-masing jawaban akan diberi skor dari 1 sampai 5 .

Hasil dari pengujian kuisioner didapatkan responden sebanyak 30 orang. Untuk itu penghitungannya adalah Skor Tertinggi $=5 \mathrm{x}$ $30=150$.

Tabel 2. Tabel pengisian kuisioner

\begin{tabular}{|c|c|c|c|c|c|c|c|c|}
\hline \multirow{2}{*}{ No } & \multirow{2}{*}{$\begin{array}{c}\text { Pertanya } \\
\text { an }\end{array}$} & $\begin{array}{c}\text { SS } \\
\text { (5) }\end{array}$ & $\begin{array}{c}\text { S } \\
(4)\end{array}$ & $\begin{array}{c}\text { N } \\
(3)\end{array}$ & $\begin{array}{c}\text { TS } \\
(2)\end{array}$ & $\begin{array}{c}\text { STS } \\
(1)\end{array}$ & \multirow{2}{*}{ Skor } & $\begin{array}{c}\text { Presenta } \\
\text { se }\end{array}$ \\
\hline 1 & P1 & 5 & 20 & 4 & 2 & 0 & 121 & $80.67 \%$ \\
\hline 2 & P2 & 5 & 5 & 18 & 2 & 0 & 103 & $68.67 \%$ \\
\hline 3 & P3 & 5 & 15 & 9 & 1 & 0 & 114 & $76.00 \%$ \\
\hline 4 & P4 & 2 & 21 & 2 & 2 & 2 & 104 & $69.33 \%$ \\
\hline 5 & P5 & 2 & 13 & 17 & 0 & 0 & 117 & $78.00 \%$ \\
\hline \multicolumn{8}{|c|}{ Rata-rata Presentase } \\
\hline
\end{tabular}

Hasil dari pengujian ni dapat dilihat pada diagram batang seperti pada Gambar 12 .

\section{Hasil Pengujian}

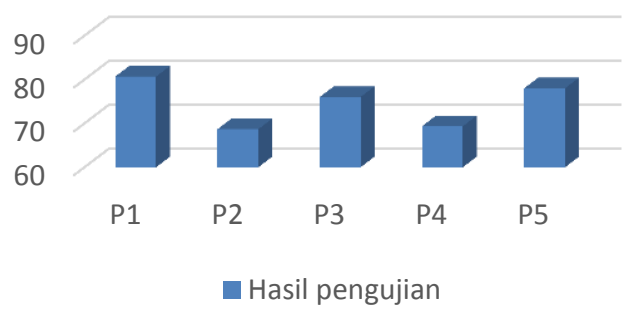

Gambar 12. Diagram hasil penilaian kuisioner

Dilihat dari Tabel 2 dan gambar diagram batang pada Gambar 7 diatas dapat disimpulkan bahwa hasil dari pengujian pada masyarakat umum dan kalangan muda menunjukkan bahwa sebesar $74.53 \%$ responden pengguna "Aplikasi Pengenalan dan Simulasi Alat Musik Sape"' dapat meningkatkan keinginan responden untuk belajar alat musik Sape' dan aplikasi mudah untuk dioperasikan.

\section{PENUTUP}

Berdasarkan pengujian yang telah dilakukan diperoleh hasil bahwa "Aplikasi Pengenalan dan Simulasi Alat Musik Sape'" telah berhasil dirancang menggunakan Construct 2 dan berjalan dengan baik pada perangkat seluler Xiaomi Redmi Note 4X yang memiliki sistem operasi Android. Berdasarkan hasil pengujian Blackbox, dapat disimpulkan bahwa semua fungsi menu dari aplikasi telah berhasil berjalan dengan baik. Sedangkan pada hasil pengujian kuisioner sebanyak 30 responden menunjukkan bahwa $74.53 \%$ menjawab dengan positif .

Dari hasil Analisa tersebut dapat simpulkan bahwa "Aplikasi Pengenalan dan
Simulasi Alat Musik Sape"' mudah untuk dioperasikan dan membantu masyarakat terutama pada kalangan muda mengingkatkan keinginan untuk belajar alat musik Sape'.

\section{DAFTAR PUSTAKA}

[1] A. D. Anuari, "Pendahuluan", Penciptaan Karya Kriya Kayu dalam Bentuk Alat Musik Sape'., p. 3, Mei. 2018.

[2] David, A. Rucitra, Fibriyenti \& Anthonio, "Pendahuluan", Aplikasi Edukasi Music Traditional Arcade Berbasis Android., vol. 5, no. 2, p.1335, Des. 2014.

[3] D. D. Meizantaka, O, D. Nurhayati, \& D. Eridani, "Abstrak", Aplikasi Simulasi dan Main Angklung (Saung) Berbasis Android., vol. 5, no.1, p.1, Jan. 2017.

[4] C. Comber, D. J. Hargreaves \& A. Colley, "Working with music technology", Girls, Boys and Techology in Music Education., vol. 10, no. 02, pp. 123-134, Jul. 2008.

[5] Hallam. S, "Educational motivation and reengangment of the disaffected", The Power of Music: a research synthesis on the impact of actively making music on the intellectual, social and personal development of children and young people. London : The International Music Education Research, 2015. 